\title{
ZOOPLANKTON OF THE NORT-WESTER PART \\ OF THE BLACK SEA IN 2016-2019 AND ASSESSMENT \\ OF THE QUALITY OF THE ENVIROMENT BY ITS INDICATORS
}

\author{
Kharytonova Yu. V., Nabokin M. V.
}

\section{INTRODUCTION}

Anthropogenic impacts of various types leading to eutrophication and pollution of the Black Sea are changing the main characteristics of all components of the aquatic ecosystem. Zooplankton plays a key role in the pelagic food web, since it binds primary producers of organic matter (phytoplankton), bacterioplankton and higher trophic levels (mainly fish) ${ }^{1}$.

Organisms of zooplankton play also an important ecological role in processes of water self-clearing due to nutrition upon detritus, bacterio- and phytoplankton, which are the main components of suspended organic matter. As a result, the water is cleared from organic and inorganic suspensions, the transparency of water increases, mineralized suspended organic matter are drawn into the cycle of substances, suspensions are deposited and accumulated on the bottom. Together with the others components of the marine ecosystem (phytoplankton, phytobenthos, zoobenthos, bacteria, fungi etc.) status of the zooplankton can be used to asses the ecological class of water quality ${ }^{2}$.

Unlike the physical and chemical indicators of the marine environment, biological indicators are far below the level of "information noise" associated with the dynamic properties of the ecosystem and are more closely related to the major stages of transformation of matter and energy. Traditionally, groups of both planktonic and benthic hydrobionts have been used to monitor the quality of the marine environment. Works carried out in accordance with the requirements of the EU Water Directive - WFD - (Directive 2000/60 / EC) and the Marine Strategy of the EU Water Directive - MSFD - (Directive 2008/56 / EC) for the classification and assessment of the reliability of various indicators - quality elements ) showed that there is a difference in the priority of indicators for open and coastal waters ${ }^{3}$.

\footnotetext{
${ }^{1}$ Alexandrov B., Minicheva G., Zaitsev Yu. Black Sea network of marine protected areas: European approaches and adaptation to expansion and monitoring in Ukraine. Management of marine protected areas: a network perspective from the Mediterranean and Black Sea / Ed. by Paul D. Goriup. Wiley-Blackwell Publ., 2017. P. 259-282.

${ }^{2}$ Alexandrov B.G., Kharytonova Yu.V. Implementation of the EU Directive on the Marine Strategy for the Sovereign Monitoring of the Zooplankton of the Marine Waters of Ukraine. The European Interation of Environmental Policy of Ukraine : Materials of the All-Ukrainian Sciences. conf. Odessa, 29-31 May 2019, ODEKU. Odessa, 2019. P. 28-37.

${ }^{3}$ Alexandrov B.G., Kharytonova Yu.V. Leadership on the zooplankton monitoring of Ukraine sea waters and the definition of their invironmental standard EU Directive on Marine Srtategy. Odessa, 2019. 33 p.
} 
For coastal ecosystems that are under much larger anthropogenic cargo than the open sea, priority is given to the fixed plant and animal species as biological indicators. For open waters, biological factors of zooplankton are more important ${ }^{4}$. Criteria elements means the components of an ecosystem, in particular its biological elements (species, habitats and their grouping), or aspects of pressure on the marine environment (biological, physical, substances, debris and energy) that are evaluated against each criterion (DIRECTIVE 2008/56/EC, 2008) ${ }^{5}$.

According to the zooplankton indicators, the ecological quality class of the studied Black Sea waters was determined on a 5 point quality scale according to the standards of Water Framework Directive of EU ("High", "Good", "Moderate", "Poor" and "Bad") 6

This research was conducted within the "Emblas-plus project" with the support of the European Union, during which the Black Sea was constantly monitored and its condition and quality were analyzed. Conducting such research allows Ukraine to integrate with the European Union.

The purpose of the reseach was to analyze the metrics of zooplankton in the Ukrainian waters of the Black Sea in accordance with expeditionary studies within the joint Black Sea monitoring by Ukraine in 2019. As well as by zooplankton indicators to conduct a assess the class of ecological status of the studied waters using 5 categories of ecological quality in accordance with the requirements of the EU Water Framework Directive and the Black Sea Integrated Monitoring and Evaluation Program (BSIMAP).

\section{Material and methods}

The main problems of the methodology for determining the quality of the aquatic environment by biological indicators of phytoplankton, zooplankton, phytobenthos and zoobenthos, which should be developed for key components of the aquatic ecosystem (criteria elements), are:

1. Justification of reference conditions (quality) of the aquatic environment, taken as indicators of good environmental conditions for WFD.

2. Search for key indicators (characteristics, metrics) of the state of life forms mentioned.

3. Temperature allocation of seasons (biological winter, spring, summer and autumn $)^{7}$.

\footnotetext{
${ }^{4}$ Alexandrov B.G., Kharytonova Yu.V. Leadership on the zooplankton monitoring of Ukraine sea waters and the definition of their invironmental standard EU Directive on Marine Srtategy. Odessa, 2019. 33 p.

${ }^{5}$ DIRECTIVE 2008/56/EC of the European Parliament and of the Council establishing a framework for Community action in the field of marine environmental policy, 17 June 2008. (MSFD, 2008/56/EC).

${ }^{6}$ Commission Decision (EU) 2017/848 of 17 May 2017 laying down criteria and methodological standards on good environmental status of marine waters and specifications and standardised methods for monitoring and assessment, and repealing Decision 2010/477/EU C/2017/2901 ELI: http://data.europa.eu/ eli/dec/2017/848/oj \

7 Руководство по организации и проведению биологического мониторинга на стационарных пунктах / Составители: Александров Б.Г. и др. Одесса, 2016. 6 с.
} 
The key geographical features of the Black Sea environmental monitoring (according to WFD - DIRECTIVE 2000/60/EC and MSFD - DIRECTIVE 2008/56/EC) are ${ }^{8}$ :

1. coastal waters - surface water bodies extending toward the shore from a line, each point of which is located one nautical mile to the sea from the nearest point of the baseline from which the width of the territorial waters is measured, extending to the outer boundary of transitional (intermediate) waters (WFD);

2. transitional or intermediate waters (transitional waters) - surface water bodies near the mouth of rivers characterized by incomplete (partial) salinity as a result of their proximity to coastal seawater, which are significantly affected by freshwater runoff (WFD);

3. Marine or open waters - all waters in the seas / oceans that do not belong to the category «coastal waters» and «transit waters» (MSFD) ${ }^{9}$.

According to the peculiarities of salinity and vertical temperature distributions, taking into account the influence of the four largest rivers (Danube, Dnieper, Dniester and Bug) on the North-Western part of the Black Sea, were identified the following sampling areas ${ }^{10}$ :

1. Coastal (surface) waters of the Danube region - catchment horizon from 0 to $10 \mathrm{~m}$ (or the upper limit of the thermocline), water salinity $<10 \%$ (transit or intermediate waters).

2. Coastal (surface) waters of the Dniester-Dnieper district - catchment horizon from 0 to $10 \mathrm{~m}$, water salinity $<10 \%$ (transit or intermediate waters).

3. Shelf (surface) waters of the Danube region to a depth of $50 \mathrm{~m}-$ catchment horizon from 0 to $10 \mathrm{~m}$, salinity of water $12-17 \%$.

4. Shelf (surface) waters of the Dniester-Dnieper region to a depth of $50 \mathrm{~m}$ - catchment horizon from 0 to $10 \mathrm{~m}$, salinity of water $12-17 \%$.

5. Open (thermocline zone) waters of the Danube district to a depth of $50 \mathrm{~m}$ - catchment horizon from 10 to $25 \mathrm{~m}$, salinity of water $12-17 \%$.

6. Open (thermocline zone) waters of the Dniester-Dnieper district to a depth of $50 \mathrm{~m}$ - catchment horizon from 10 to 25 , water salinity $12-17 \%$.

7. 7.Open waters (surface) - outside the depth of $50 \mathrm{~m}$ - catchment horizon from 0 to $10 \mathrm{~m}$.

\footnotetext{
${ }^{8}$ Alexandrov B.G. General remarks on the method of quantitative accounting of zooplankton and the use of an integrated assessment of the state of zooplankton to determine the quality of the marine environment (calculation methodology, quality assessment scales). Workshop on the NPMS and JOSS Biological Monitoring Methods. 2016. URL: http://emblasproject.org/gallery/npms-joss-biology-training.

9 Aleksandrov B., Arashkevich E., Gubanova A., Korshenko A. Black Sea Monitoring Guidelines Mesozooplankton. EU/UNDP Project: Improving Environmental Monitoring in the Black Sea - EMBLAS. Project Activity 3: Development of cost-effective and harmonized biological and chemical monitoring programmes in accordance with reporting obligations under multilateral environmental agreements, the WFD and the MSFD. October 2014. $31 \mathrm{p}$.

${ }^{10}$ Alexandrov B.G., Kharytonova Yu.V. Leadership on the zooplankton monitoring of Ukraine sea waters and the definition of their invironmental standard EU Directive on Marine Srtategy. Odessa, 2019. 33 p.
} 
8. Open waters (thermocline zone) - outside the depth of $50 \mathrm{~m}$ - catchment horizon from 10 to $25 \mathrm{~m}$.

9. Opet waters (cold intermediate layer zone) - outside the depth of $50 \mathrm{~m}-$ catchment horizon from 25 to $100 \mathrm{~m}^{11}$.

Sampling and assessment of the quality of the aquatic environment of the Black Sea on zooplankton indicators took place within the framework of the international project Emblas-plus during the Ukrainian-Georgian expedition (NPMS) during autumn 2019.

In accordance with sampling areas of the north-western part of the Black Sea were identified the following regions, where established the main metrics of zooplancton and ecological quality class was established:

1. Dnipro-Bug region.

2. Dniester region.

3. Danube region.

4. Central region.

5. Mixing zone.

Zooplankton was collected with a Juday plankton net $\left(0.1 \mathrm{~m}^{2}\right.$ opening, $150 \mu \mathrm{m}$ mesh size). In the shallow area samples were taken from the bottom to surface and in more deeper places, samples were collected from the upper mixed layer, thermocline layer and under the thermocline. Total were taken a 23 samples at the 20 stations of investigatios aquatories on 2019 (fig. 1). On 2016 were taken 36 samples at the 15 stations, on 2017 - 17 samples at the 11 stations (fig. 2).

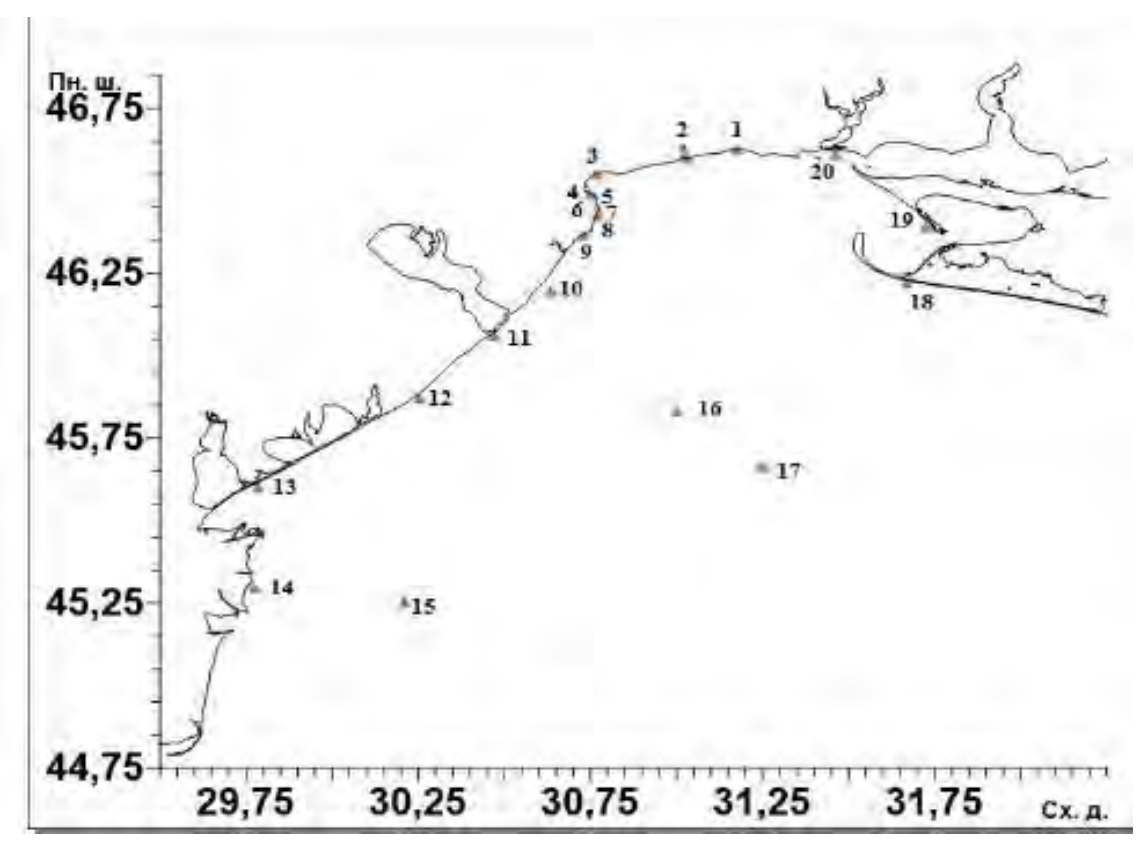

Fig. 1. Zooplankton sampling map for summer 2019

\footnotetext{
${ }^{11}$ Alexandrov B.G., Kharytonova Yu.V. Leadership on the zooplankton monitoring of Ukraine sea waters and the definition of their invironmental standard EU Directive on Marine Srtategy. Odessa, 2019. 33 p. 


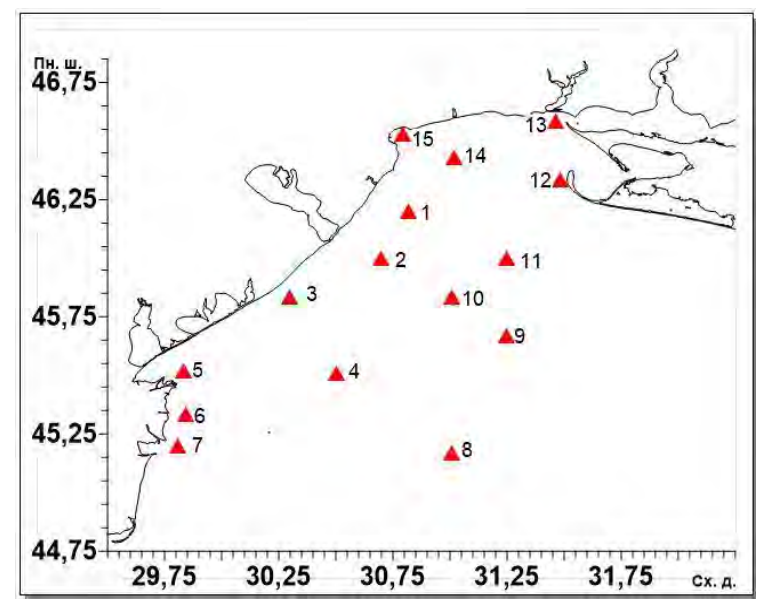

2016

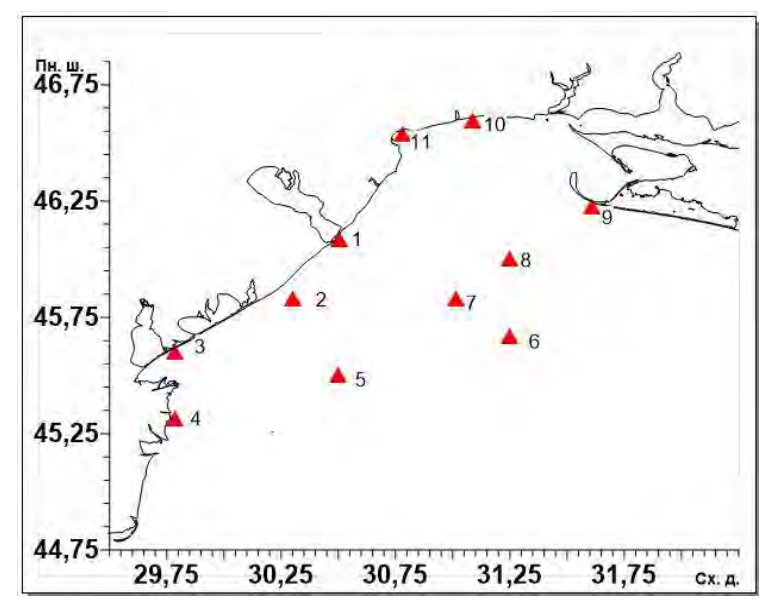

2017

Fig. 2. Zooplankton sampling map for 2016 and 2017

Zooplankton samples were preserved using $4 \%$ formaldehyde buffered to pH 8-8.2 with disodiumtetraborate (borax) $\left(\mathrm{Na}_{2} \mathrm{~B}_{4} \mathrm{O}_{3} \cdot 10 \quad \mathrm{H}_{2} \mathrm{O}\right)$ formalin solution (1 part 40\% formaldehyde solution and 9 parts water-sample) and stored in plastic containers ${ }^{12}$. In the laboratory, the samples were concentrated to $100-200 \mathrm{ml}$ and processed total samples to avoid losing rare species occurrence. A Bogorov's chamber was used for quantitative assessment (abundance and biomass calculation, using species individual weight) and qualitative (taxonomic structure) processing of samples ${ }^{13}$. Zooplankton species were determined by several determinants ${ }^{14,15,16}$.

Basic concepts used in marine quality assessment (MSFD):

1. Metric - what can be measured, that is, the various characteristics used in assessing the quality of the aquatic environment.

2. Good ecological status (GES or GenS). To determine the GES of marine ecosystems, a review of methodological standards was developed within the MSFD, which included a description of the indicators for 11 descriptors.

3. Initial conditions, to human influence (reference period, pristine conditions).

\footnotetext{
12 Методические рекомендации по сбору и обработке материалов при гидробиологических исследованиях. Зоопланктон и его продукция. Ленинград : ЗИН, 1984. 35 с.

13 Сбор и обработка зоопланктона в рыбоводных водоёмах. Методическое руководство (с определителем основных пресноводных видов)/ О.Е. Тевяшова. Ростов-на-Дону: ФГУП «АзНИРХ», 2009. 84 с.

${ }^{14}$ Определитель фауны Черного и Азовского морей [Текст]: в 3т. / под общ. ред. Ф.Д. МордухайБолтовского. Киев : Наукова думка, 1968. Т. І: Свободноживущие беспозвоночные. Простейшие, губки, кишечнополостные, черви, щупальцевые. 437 с.

${ }^{15}$ Определитель фауны Черного и Азовского морей [Текст]: в 3т. / под общ. ред. Ф.Д. МордухайБолтовского. Киев : Наукова думка, 1969. Т. II : Свободноживущие беспозвоночные. Ракообразные. $536 \mathrm{c}$.

${ }^{16}$ Определитель фауны Черного и Азовского морей [Текст]: в 3т. / под общ. ред. Ф.Д. МордухайБолтовского. Киев : Наукова думка, 1972. Т. ІІІ. Свободноживущие беспозвоночные. Членистоногие (кроме ракобразных), молюски, иглокожие, щетинкочелюстные, хордовые. 340 с.
} 
4. Relative Ecological Quality Ratio (EQR) is the ratio of the metric value in the study area to the reference conditions. Its value is between 0 and 1 (Commission Decision (EU) 2017/848, 2017).

The overall classification of the ecological status of water according to WFD is divided into five classes (table 1$)^{17}$.

Table 1

Classification of the ecological status of water according to WFD (DIRECTIVE 2008/56/EC, 2008)

\begin{tabular}{|c|c|c|c|c|c|}
\hline Quality & High & Good & Medium & Poor & $\mathrm{Bad}$ \\
\hline $\begin{array}{l}\text { The degree } \\
\text { of } \\
\text { deviation } \\
\text { from the } \\
\text { norm }\end{array}$ & $\begin{array}{c}\text { None } \\
\text { or changes in } \\
\text { biological, physical, } \\
\text { chemical and } \\
\text { hydromorphological } \\
\text { quality elements are } \\
\text { very small } \\
\text { (standard) }\end{array}$ & $\begin{array}{c}\text { Weak } \\
\text { deviation of } \\
\text { biological } \\
\text { elements of } \\
\text { water quality } \\
\text { from } \\
\text { reference } \\
\text { values }\end{array}$ & $\begin{array}{c}\text { Moderate } \\
\text { deviation of } \\
\text { biological } \\
\text { elements of } \\
\text { water quality } \\
\text { from } \\
\text { reference } \\
\text { values }\end{array}$ & $\begin{array}{c}\text { Strong } \\
\text { deviation of } \\
\text { biological } \\
\text { elements of } \\
\text { water quality } \\
\text { from } \\
\text { reference } \\
\text { values }\end{array}$ & $\begin{array}{c}\text { Critical } \\
\text { deviation of } \\
\text { biological } \\
\text { elements of } \\
\text { water quality } \\
\text { from } \\
\text { reference } \\
\text { values }\end{array}$ \\
\hline
\end{tabular}

The ecological quality ratio index (EQR) based on the integral indicator of zooplankton status $\left(\mathrm{K} \int\right)$ was calculated by the formula ${ }^{18}$.

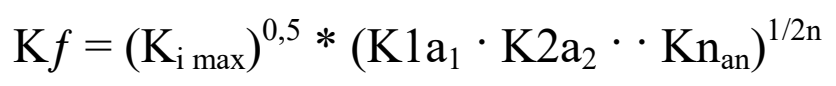

where $\mathrm{K} 1, \mathrm{~K} 2, \mathrm{Kn}$ are metrics (different characteristics of zooplankton);

$\mathrm{a} 1, \mathrm{a} 2$, and an are the weights of the metrics; $\mathrm{n}$ is the number of metrics. Conditions: $0<\mathrm{Ki} \leq 1$ and $0<\mathrm{ai} \leq$.

The following metrics of zooplankton were used as ecological indicators in the environmental monitoring:

1. Total biomass of zooplankton (B), $\mathrm{mg}^{-3}$;

2. Noctiluca scintillans (Noc) biomass, $\%$ of total biomass;

3. Copepoda (Cop) biomass, \% of total biomass;

4. Jelly biomass - Scyphozoa, Hydrozoa and Ctenophora jellyfish (Jel),\% of total biomass;

5. Shannon number index $(\mathrm{Ha})$, Beat* $^{*} \mathrm{ex}^{-1} 19$.

Since the integral indicator of the state of zooplankton must primarily reflect the state of the aquatic environment for the protection and reproduction of biological diversity, the weighting coefficients for each metric were

\footnotetext{
${ }^{17}$ DIRECTIVE 2008/56/EC of the European Parliament and of the Council establishing a framework for Community action in the field of marine environmental policy, 17 June 2008. (MSFD, 2008/56/EC).

${ }^{18}$ Kharytonova Yu.V. Analysis of the ecological status of the north-western part of the Black Sea of zooplankton indicators according to the standards of the EU Directive on Marine Srtategy / Yu.V. Kharytonova, V.G. Dyadychko. Monitoring and Conservation of Biodiversity in Ukraine : Animal World : Materials of the conference / Series: "Conservation Biology in Ukraine". Vip. 16. Vol. 2. Kyiv; Chernivtsi: Druk Art, 2020. P. 221-229.

${ }^{19}$ Alexandrov B.G., Kharytonova Yu.V. Leadership on the zooplankton monitoring of Ukraine sea waters and the definition of their invironmental standard EU Directive on Marine Strategy. Odessa, 2019. 33 p.
} 
determined by the value of the correlation coefficient of quantitative values of this quantitative value Shannon by number (Ha). The weight value of $\mathrm{Ha}$ itself was assumed to be 0.9 because it could not be equal to one ${ }^{20}$.

Based on the results of long-term monitoring of the status of zooplankton within the Ukrainian part of the Black Sea and the Danube Delta, the quality of the aquatic environment is analyzed. Water quality was determined in different seasons on a five-point scale of ecological status from excellent to bad. The results are shown in the table 2 and 3.

The main problems of the methodology for determining the quality of the aquatic environment by biological indicators of phytoplankton, zooplankton, phytobenthos and zoobenthos, which should be developed for key components of the aquatic ecosystem (criteria elements), are:

1. Justification of reference conditions (quality) of the aquatic environment, taken as indicators of good environmental conditions for WFD.

2. Search for key indicators (characteristics, metrics) of the state of life forms mentioned.

3. Temperature allocation of seasons (biological winter, spring, summer and autumn $)^{21}$.

Table 2

The value of the integral zooplankton (EQR) status indicator for determining the quality of Ukrainian marine waters ${ }^{22}$

\begin{tabular}{|l|c|c|c|c|c|}
\hline \multirow{2}{*}{ Season } & \multicolumn{5}{|c|}{ Sea water quality } \\
\cline { 2 - 6 } & High & Good & Moderate & Poor & Bad \\
\hline \multicolumn{7}{|c|}{1} & 2 & 3 & 4 & 5 & 6 \\
\hline \multicolumn{7}{|c|}{ Coastal waters, Danube area } \\
\hline Spring & $>0.939$ & $0.939-0.925$ & $0.924-0.915$ & $0.914-0.881$ & $<0.881$ \\
\hline Summer & $>0.667$ & $0.667-0.631$ & $0.630-0.565$ & $0.564-0.487$ & $<0.487$ \\
\hline Autumn & $>0.910$ & $0.910-0.899$ & $0.898-0.890$ & $0.889-0.867$ & $<0.867$ \\
\hline Winter & $>0.743$ & $0.743-0.733$ & $0.732-0.709$ & $0.708-0.699$ & $<0.699$ \\
\hline \multicolumn{7}{|c|}{ Coastal waters, Dnestrovsko-Dniprovs'kyi district } & \\
\hline Spring & $>0.900$ & $0.900-0.883$ & $0.882-0.863$ & $0.862-0.789$ & $<0.789$ \\
\hline Summer & $>0.215$ & $0.215-0.167$ & $0.166-0.094$ & $0.093-0.054$ & $<0.054$ \\
\hline Autumn & $>0.871$ & $0.871-0.849$ & $0.848-0.841$ & $0.840-0.827$ & $<0.827$ \\
\hline Winter & $>0.837$ & $0.837-0.804$ & $0.803-0.789$ & $0.788-0.651$ & $<0.651$ \\
\hline
\end{tabular}

\footnotetext{
${ }^{20}$ Alexandrov B.G., Kharytonova Yu.V. Implementation of the EU Directive on the Marine Strategy for the Sovereign Monitoring of the Zooplankton of the Marine Waters of Ukraine. The European Interation of Environmental Policy of Ukraine : Materials of the All-Ukrainian Sciences. conf. Odessa, 29-31 May 2019, ODEKU. Odessa, 2019. Р. 28-37.

21 Руководство по организации и проведению биологического мониторинга на стационарных пунктах / Составители: Александров Б.Г. и др. Одесса, 2016. 6 с.

${ }^{22}$ Alexandrov B.G., Kharytonova Yu.V. Leadership on the zooplankton monitoring of Ukraine sea waters and the definition of their invironmental standard EU Directive on Marine Srtategy. Odessa, 2019. 33 p.
} 
Table 2 (Continued)

\begin{tabular}{|l|c|c|c|c|c|}
\hline \multicolumn{1}{|c|}{1} & 2 & 3 & 4 & 5 & 6 \\
\hline Spring & $>0.927$ & $0.927-0.917$ & $0.916-0.899$ & $0.898-0.864$ & $<0.864$ \\
\hline Summer & $>0.538$ & $0.538-0.511$ & $0.510-0.477$ & $0.476-0.382$ & $<0.382$ \\
\hline Autumn & $>0.941$ & $0.941-0.928$ & $0.927-0.914$ & $0.913-0.884$ & $<0.884$ \\
\hline Winter & $>0.603$ & $0.603-0.597$ & $0.596-0.593$ & $0.592-0.591$ & $<0.591$ \\
\hline \multicolumn{7}{|c|}{ Shelf zone, surface layer $(0-10$ m), Dniester-Dnipro district } \\
\hline Spring & $>0.927$ & $0.927-0.912$ & $0.911-0.897$ & $0.896-0.835$ & $<0.835$ \\
\hline Summer & $>0.872$ & $0.872-0.854$ & $0.853-0.828$ & $0.827-0.599$ & $<0.599$ \\
\hline Autumn & $>0.832$ & $0.832-0.713$ & $0.712-0.618$ & $0.617-0.581$ & $<0.581$ \\
\hline \multicolumn{7}{|c|}{ Open water, surface layer (0-10 m) } \\
\hline Spring & $>0.864$ & $0.864-0.851$ & $0.850-0.838$ & $0.837-0.806$ & $<0.806$ \\
\hline Summer & $>0.706$ & $0.706-0.686$ & $0.685-0.684$ & $0.683-0.674$ & $<0.674$ \\
\hline Autumn & $>0.463$ & $0.463-0.452$ & $0.451-0.321$ & $0.320-0.129$ & $<0.129$ \\
\hline Winter & $>0.944$ & $0.944-0.928$ & $0.927-0.903$ & $0.902-0.889$ & $<0.889$ \\
\hline \multicolumn{7}{|c|}{ Shelf zone and open water, thermocline zone (10-25 m) } & \\
\hline Spring & $>0.942$ & $0.942-0.926$ & $0.925-0.911$ & $0.910-0.892$ & $<0.892$ \\
\hline Summer & $>0.647$ & $0.647-0.635$ & $0.634-0.617$ & $0.616-0.602$ & $<0.602$ \\
\hline Autumn & $>0.924$ & $0.924-0.907$ & $0.906-0.895$ & $0.894-0.866$ & $<0.866$ \\
\hline Winter & $>0.396$ & $0.396-0.340$ & $0.339-0.280$ & $0.279-0.268$ & $<0.268$ \\
\hline \multicolumn{7}{|c|}{ Open water, cold intermediate layer (25-100 m) } & $<0.918$ \\
\hline Spring & $>0.940$ & $0.940-0.937$ & $0.936-0.929$ & $0.928-0.918$ & $<0.701$ \\
\hline Summer & $>0.893$ & $0.893-0.876$ & $0.875-0.812$ & $0.811-0.701$ & $<0.891$ \\
\hline Autumn & $>0.949$ & $0.949-0.942$ & $0.941-0.923$ & $0.922-0.891$ & 0.353 \\
\hline Winter & $>0.945$ & $0.945-0.943$ & $0.942-0.935$ & $0.934-0.902$ & \\
\hline
\end{tabular}

\section{The value of the integral zooplankton status indicator for determining the quality of transitional waters of the Ukrainian part of the Danube Delta ${ }^{23}$}

\begin{tabular}{|c|c|c|c|c|}
\hline High & Good & Moderate & Poor & Bad \\
\hline \multicolumn{5}{|c|}{ Spring } \\
\hline$>0,483$ & $0,483-0,437$ & $0,436-0,365$ & $0,364-0,268$ & $<0,268$ \\
\hline \multicolumn{5}{|c|}{ Summer } \\
\hline$>0,584$ & $0,584-0,513$ & $0,512-0,411$ & $0,410-0,376$ & $<0,376$ \\
\hline \multicolumn{5}{|c|}{ Autumn } \\
\hline$>0,663$ & $0,663-0,620$ & $0,619-0,539$ & $0,538-0,473$ & $<0,473$ \\
\hline
\end{tabular}

\section{Results of the investigation. Taxonomic structure, abundance, biomass of zooplankton and forage zooplankton for fish}

In 2019 totally 49 taxons of zooplankton were registered: Protista - 3, Coelenterata - 2, Ctenophora - 2, Rotatoria -3, Polychaeta - 4, Gastropoda-

\footnotetext{
${ }^{23}$ Kharytonova Yu. V. Analysis of transition waters of the Ukranian Black sea shelf by zooplankton indicators (on example of the Danube Delta). Visnik of the Odessa National University. Seriya: Biology. Volume 24, Issue 2 (45) 2019. Odessa ONU. P. 88-96.
} 
1, Bivalvia -1 , Tentaculata -1 , Crustacea -12 (including Cladocera -7 , Copepoda - 14, Cirripedia - 1, Cumacea - 1, Amphipoda - 1, Decapoda-1), Acari -1 , Chaetognatha -1 , Chordata -3 taxons. Most of them belong to the typical inhabitants of the sea waters of the Black sea. Bosmina longirostris and Cornigerius maeoticus live primarily in oligohaline and fresh waters. Holoplankton includes 35 taxons, meroplankton - 14 taxons. Most of them belong to the forage zooplankton for fish.

In 2019 average abundance of zooplankton was 19641,83 ind $^{*} \mathrm{~m}^{-3}$, biomass $281,14 \mathrm{mg}^{*} \mathrm{~m}^{-3}$. The highest average abundance and biomass of zooplankton was registered in the Dnieper area -52735 ind $^{*} \mathrm{~m}^{-3}$ and $715,53 \mathrm{mg}^{*} \mathrm{~m}^{-3}$ respectivelly. In the Danube region average abundance and biomass of the zooplankton were similar to those in the Dnieper region -49702 ind $^{*} \mathrm{~m}^{-3}$ and $692,33 \mathrm{mg}^{*} \mathrm{~m}^{-3}$ respectivelly. In the Dniester area average abundance and biomass of zooplankton were lower than in two previous regions 17747 ind $^{*} \mathrm{~m}^{-3}$ and $96,65 \mathrm{mg}^{*} \mathrm{~m}^{-3}$ respectivelly. In the zone of mixed waters abundance of zooplankton was an order of magnitude less than in previous aquatories -7988 ind* $\mathrm{m}^{-3}$ but the biomass was higher than in Dniester region but lower than in Danube and Dnieper regions - 329,18 $\mathrm{mg}^{*} \mathrm{~m}^{-3}$ (fig. 3). At most of the stations dominant taxons by abundance and biomass were Copepoda (Acartia spp., Oithona davisae) Cladocera (Penilia avirostris) and larvae of benthic invertebrates.

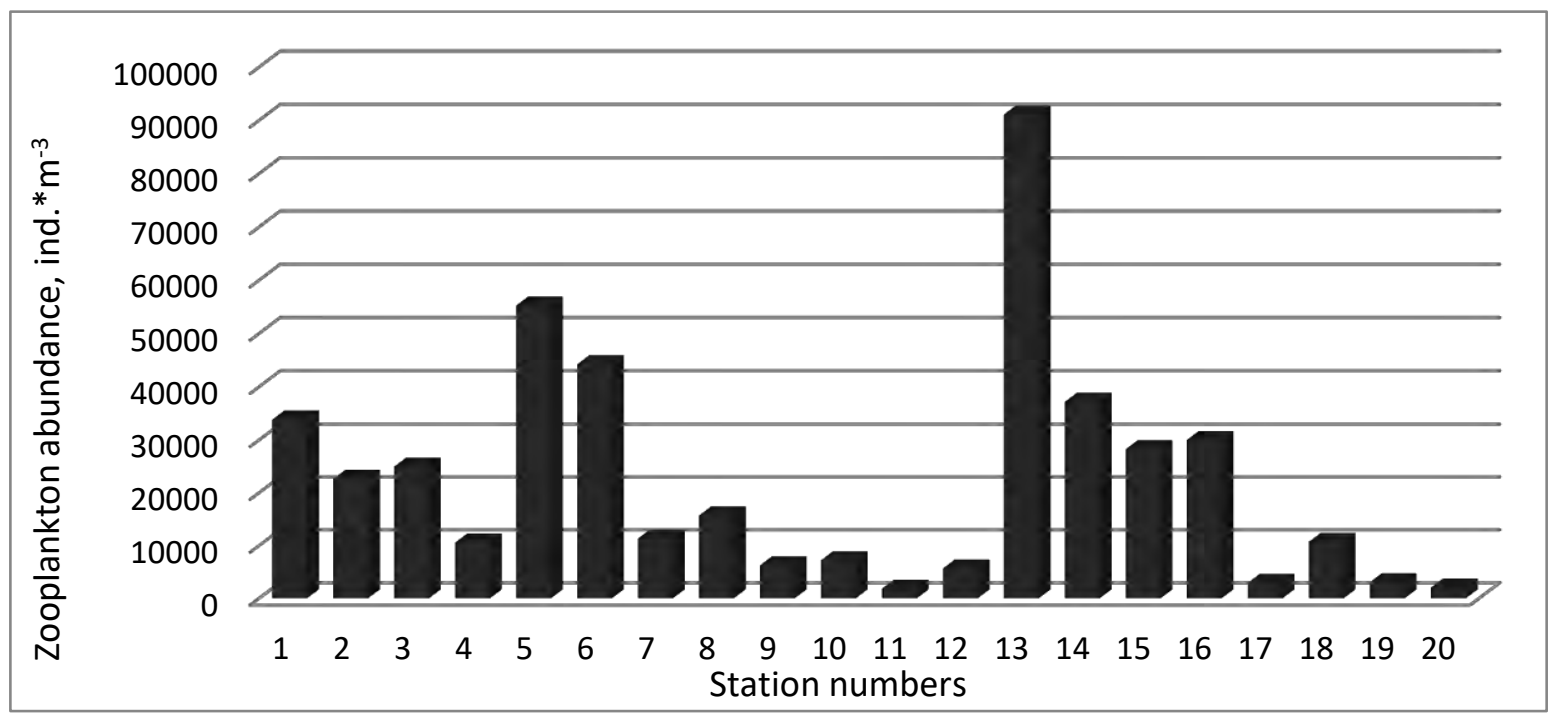

Fig. 3. Zooplankton abundance (ind.* $\mathrm{m}^{-3}$ ) in North-Western Black sea on 2019

Most of registered taxons of zooplankton belong to the forage base for fish. At all the stations organisms of the forage zooplankton played dominant role in forming of zooplankton biomass. Percentage of the non-forage zooplankton in the total biomass was less than $23 \%$. Average biomass of the forage 
zooplankton was $220 \mathrm{mg}^{*} \mathrm{~m}^{-3}$, so the status of forage base of planktophagous fishes was relatively good. Maximal biomass of the forage zooplankton $1524,08 \mathrm{mg}^{*} \mathrm{~m}^{-3}$ was registered at the station MMS-19-18 (Tendra island). Minimal biomass of the forage zooplankton $-5,02 \mathrm{mg}^{*} \mathrm{~m}^{-3}$ was registered at the station MMS-19-9 in the Dniester region (fig. 4).

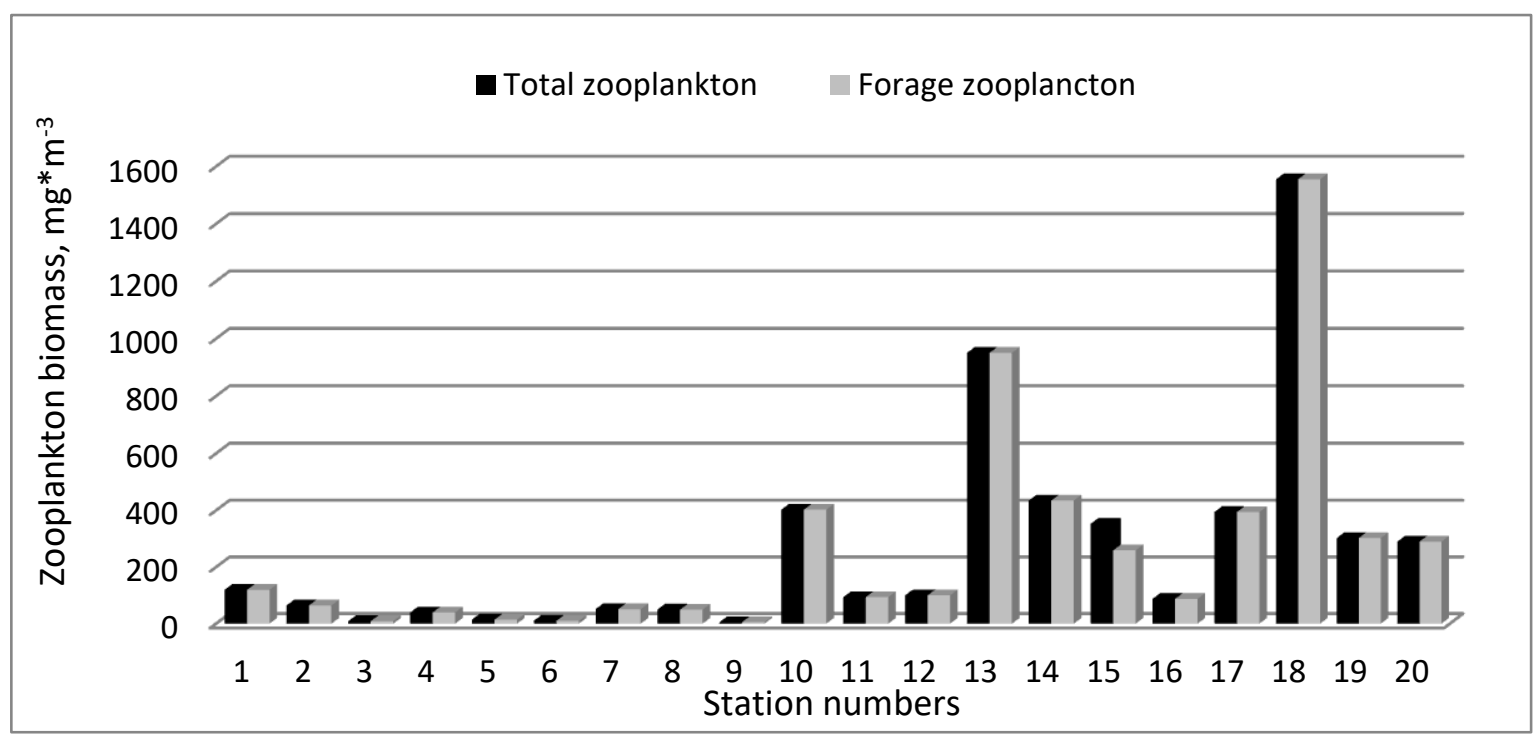

Fig. 4. Biomass of total and forage zooplankton $\left(\mathrm{mg}^{*} \mathrm{~m}^{-3}\right)$ in North-Western Black sea on 2019

In comparison with data for 2016 and 2017 years in 2019 taxonomic composition of zooplankton was more diverse (27 taxons in 2016, 26 in 2017).

Comparing data for 2016 and 2017 years we can see that average abundance and biomass of zooplankton in 2019 was similar to those in 2016 $\left(10299,00\right.$ ind $^{*} \mathrm{~m}^{-3}$ and $\left.182,62 \mathrm{mg}^{*} \mathrm{~m}^{-3}\right)$ and much more higher than in 2017 $\left(1713,95\right.$ ind $^{*} \mathrm{~m}^{-3}$ and $\left.29,99 \mathrm{mg}^{*} \mathrm{~m}^{-3}\right)$. Dominant taxons and spatial distribution of zooplakton in 2019 was similar to those in 2016 and 2017.

In comparison with data for 2016 and 2017 years in 2019 average biomass of forage zooplankton was approximately 10 times higher than in 2016 and $2017\left(23,8 \mathrm{mg}^{*} \mathrm{~m}^{-3}\right.$ and $21,4 \mathrm{mg}^{*} \mathrm{~m}^{-3}$ respectively).

\section{Environmental class status of the investigated aquatories}

According to the defined zooplankton metrics an integrated quality indicator (EQR) was calculated for each stations, regions and seasons during 2016, 2017 and 2019. In spring 2016 the coastal waters of the Dniester, Central and Mixing regions had a "Bad" quality class at all research stations. Within the Dnipro-Buz region all stations had "Moderate" and "Poor" water quality. Only the waters of the Danube region showed the best "High" quality of the aquatic environment (table 4, fig. 5). 
Table 4

Environmental class status (EQR) of the investigated aquatories of 2016

\begin{tabular}{|c|l|c|c|}
\hline N & \multicolumn{1}{|c|}{ Subregion } & $\begin{array}{c}\text { Ecological Quality } \\
\text { Ratio (EQR) }\end{array}$ & Ecological Status Class \\
\hline 1 & Dniester region & 0,708 & "Bad" \\
\hline 2 & Mixing zone & 0,791 & "Bad" \\
\hline 3 & Danube region & 0,642 & "High" \\
\hline 4 & Central region & 0,809 & "Bad" \\
\hline 5 & Dnipro-Bug region & 0,797 & "Moderate" \\
\hline
\end{tabular}

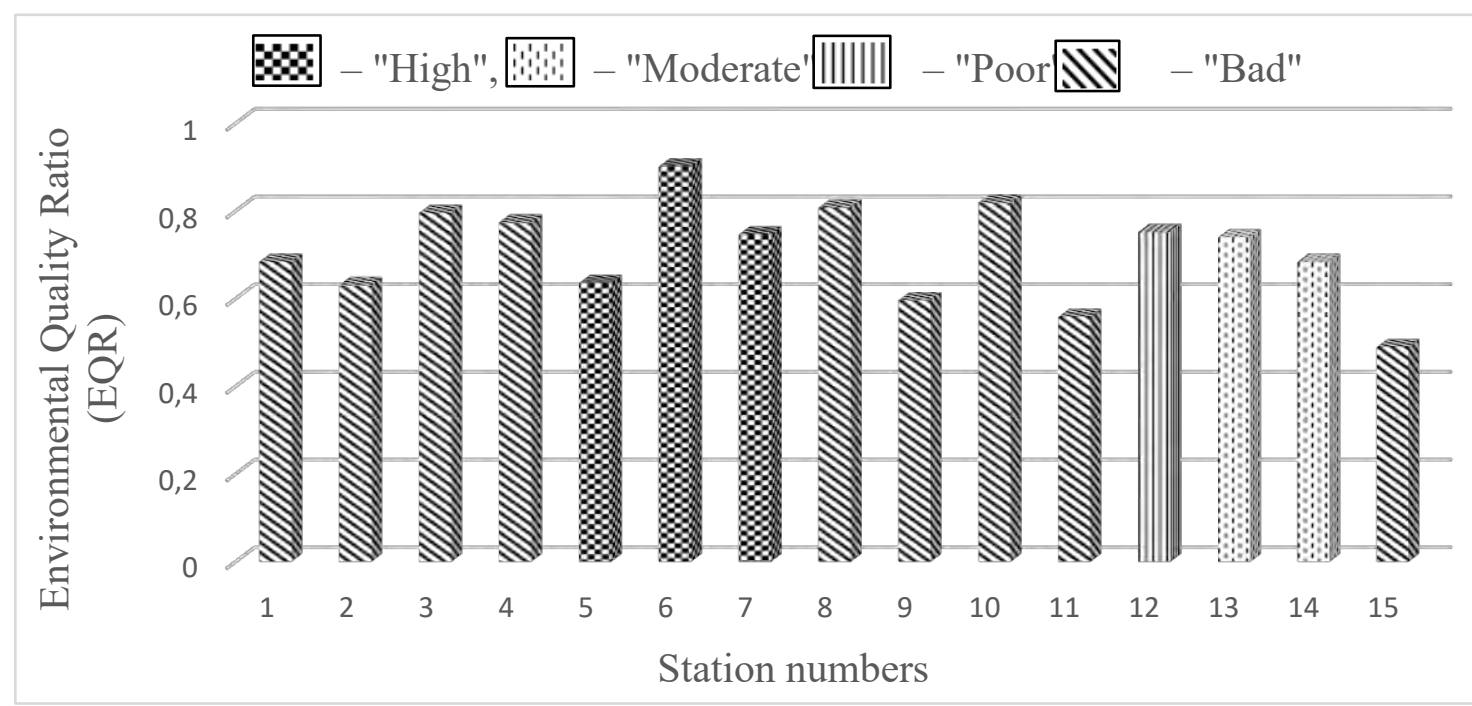

Fig. 5. Ecological quality class of the studied aquatories in spring of 2016

As a result of the calculation of the integrated zooplankton index in spring and summer 2017 was found that in the Mixing and Central regions of the North-Western part of the Black Sea was a "Bad" quality of the aquatic environment. The Dniester and Danube regions showed "Moderate" water quality. Only the waters of the Dnipro-Bug region showed "High" environmental quality ratio (table 5 , fig. 6 ).

Table 5

Environmental class status (EQR) of the investigated aquatories of 2017

\begin{tabular}{|c|l|c|c|c|c|}
\hline \multirow{2}{*}{$\mathrm{N}$} & \multirow{2}{*}{ Subregion } & \multicolumn{2}{c|}{$\begin{array}{c}\text { Ecological Quality } \\
\text { Ratio (EQR) }\end{array}$} & \multicolumn{2}{c|}{ Ecological Status Class } \\
\cline { 3 - 6 } & & Summer & Spring & Summer & Spring \\
\hline 1 & Dniester region & & 0,619 & & "Moderate" \\
\hline 2 & Danube region & 0,549 & 0,523 & "Bad" & "Moderate" \\
\hline 3 & Dnipro-Bug region & & 0,582 & & "High" \\
\hline 4 & Mixing zone & & 0,568 & & "Bad" \\
\hline 5 & Central region & 0,660 & 0,586 & "Poor" & "Bad" \\
\hline
\end{tabular}




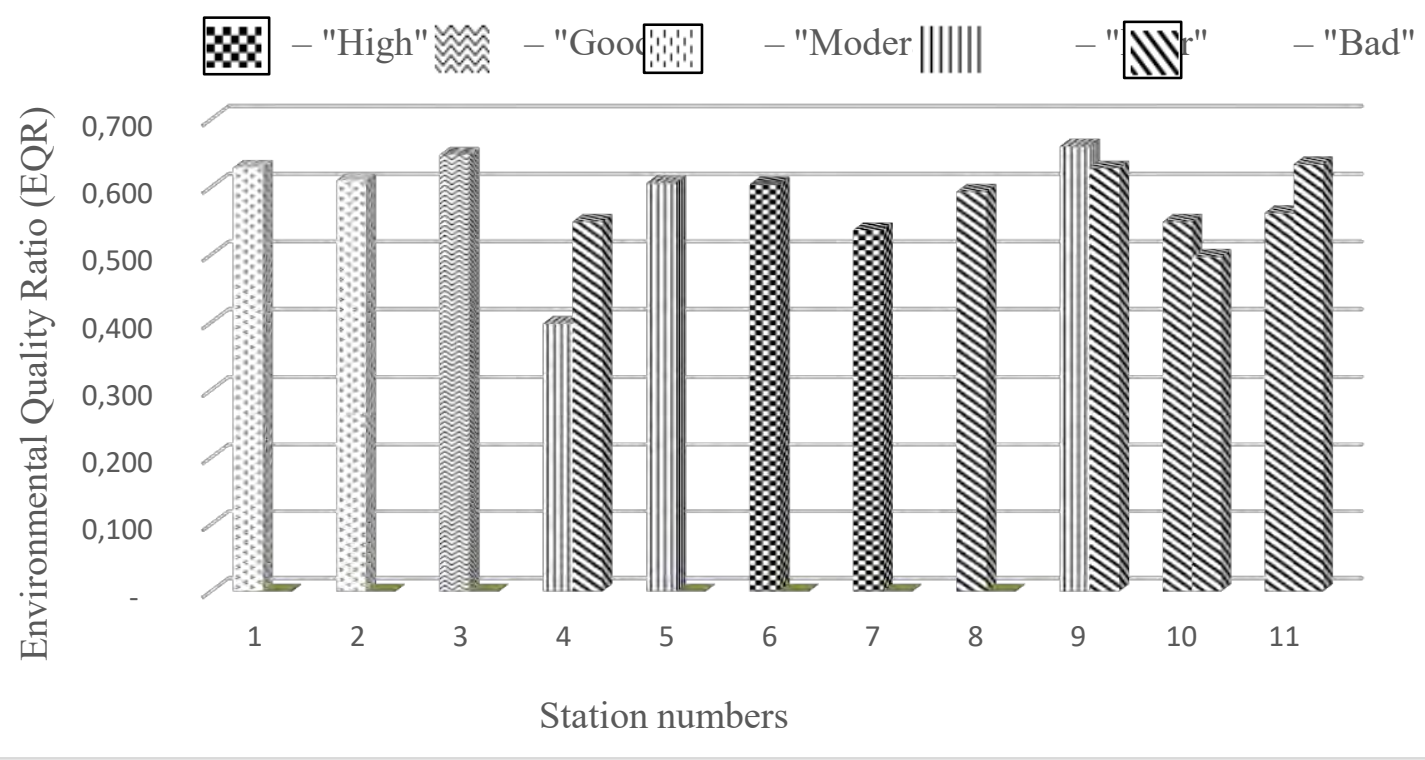

Fig. 6. Ecological quality class of the studied aquatories in summer (1 row) and spring ( 2 row) of 2017

In 2019 the most of investigated aquatories had "Bad" ecological status. The coastal waters Dnipro-Bug ragion had "Bad" environmental class status at all stations. The waters on Mixing zone were ranged from "High" to "Bad" quality. Only the waters of Danube region had "High" environmental class status at all stations (table 6, fig. 7).

Table 6

Environmental class status (EQR) of the investigated aquatories of 2019

\begin{tabular}{|c|l|c|c|c|c|c|}
\hline \multirow{2}{*}{ N } & \multirow{2}{*}{ Subregion } & \multirow{2}{*}{$\begin{array}{c}\text { Index of } \\
\text { Shannon } \\
\text { (Average) }\end{array}$} & \multicolumn{2}{|c|}{$\begin{array}{c}\text { Ecological Quality } \\
\text { Ratio (EQR) }\end{array}$} & \multicolumn{2}{|c|}{ Ecological Status Class } \\
\cline { 4 - 7 } & & Summer & Autumn & Summer & Autumn \\
\hline 1 & Dnipro-Bug region & 2,59 & 0,697 & & "Bad" & \\
\hline 2 & Dniester region & 2,51 & & 0.737 & & "Bad" \\
\hline 3 & Danube region & 2,51 & & 0.799 & & "High" \\
\hline 4 & Mixing zone & 2,98 & 0,639 & & "Bad" & \\
\hline
\end{tabular}

As a result of monitoring for 2016, 2017 and 2019, the environmental class status in most of the investigated aquatories showed a "Bad" quality class, rarely "Moderate" or "Poor", "High" class of water quality was noted only in Danube region (in 2019 and 2016) and in Dnipro-Bug region (2017).

Comparing data for 2016 and 2019 years we conclude that environmental class status of investigated aquatories in 2019 was similar to that in 2016 and 2017. Most of them had "Bad" ecological status. 


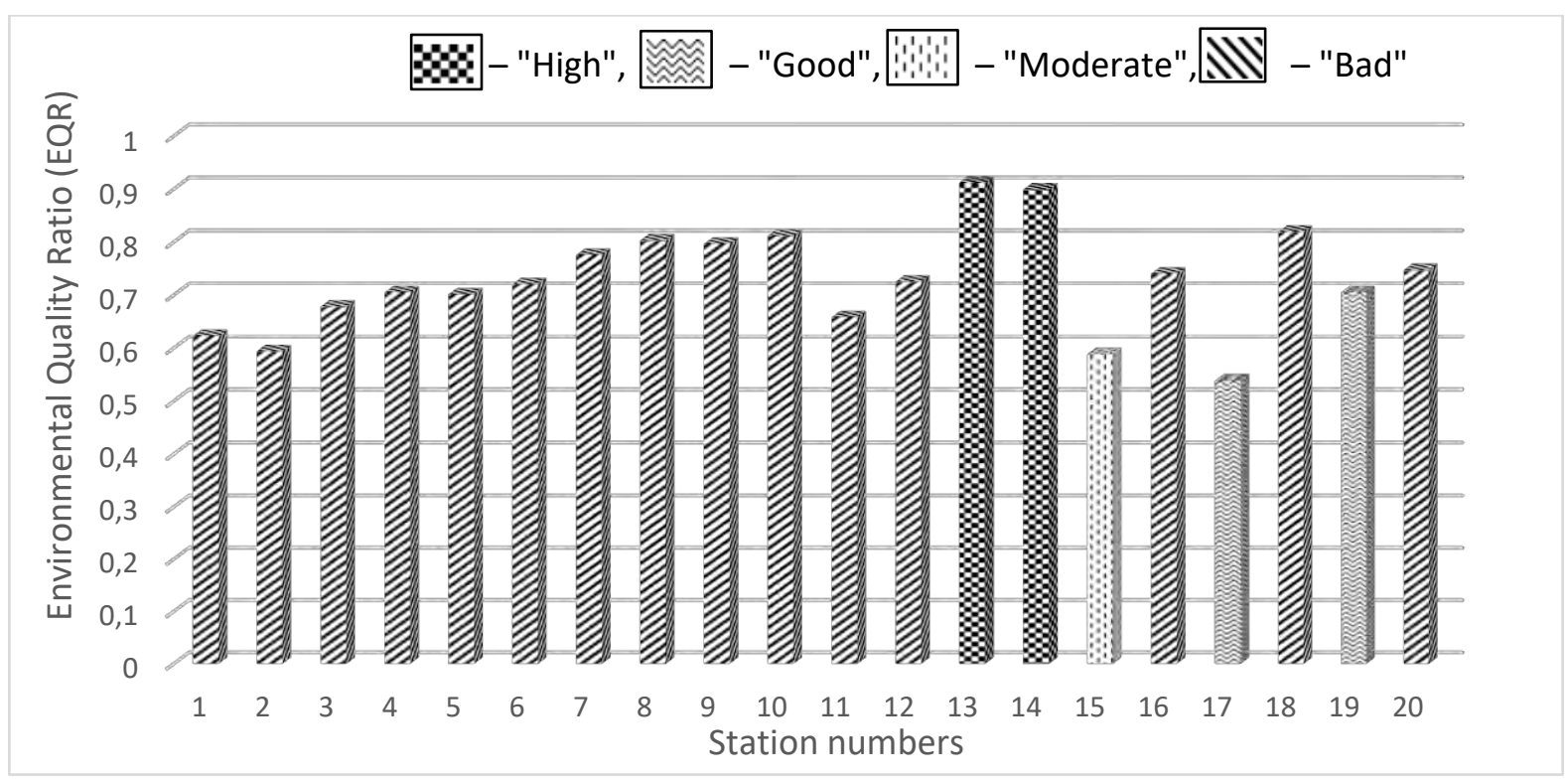

Fig. 7. Ecological quality class of the studied aquatories in summer-autumn of 2019

\section{CONCLUSIONS}

In 2019 totally 49 taxons of zooplankton were registered, so in 2019 taxonomic composition of zooplankton was more diverse than in previous years (27 taxons in 2016, 26 in 2017). Most of them belong to the forage zooplankton for fish.

In 2019 average abundance of zooplankton was 19641,83 ind* $\mathrm{m}^{-3}$, biomass $281,14 \mathrm{mg}^{*} \mathrm{~m}^{-3}$. The highest average abundance and biomass of zooplankton were registered in the Dnipro-Bug region. Average abundance and biomass of zooplankton in 2019 was similar to those in $2016\left(10299,00\right.$ ind $^{*} \mathrm{~m}^{-3}$ and $\left.182,62 \mathrm{mg}^{*} \mathrm{~m}^{-3}\right)$ and much more higher than in $2017\left(1713,95 \mathrm{ind}^{*} \mathrm{~m}^{-3}\right.$ and $\left.29,99 \mathrm{mg}^{*} \mathrm{~m}^{-3}\right)$. At most of the stations dominant taxons by abundance and biomass were Copepoda, Cladocera and larvae of benthic invertebrates.

In 2019 at all stations organisms of the forage zooplankton played dominant role in forming of zooplankton biomass. Average biomass of the forage zooplankton was $220 \mathrm{mg}^{*} \mathrm{~m}^{-3}$, so the status of forage base of planktophagous fishes was relatively good. In 2019 average biomass of forage zooplankton was approximately 10 times higher than in 2016 and 2017 $\left(23,8 \mathrm{mg}^{*} \mathrm{~m}^{-3}\right.$ and $21,4 \mathrm{mg}^{*} \mathrm{~m}^{-3}$ respectively).

According to the zooplankton metrics and EQR integral index in 2019 most of investigated aquatories had Bad ecological status, only the waters of Danube region had "High" environmental class status. In 2016 the worse water quality was in Dniester, Central and Mixing region that had ("Bad") environmental class status. The waters of the Danube region showed the best "High" quality of the aquatic environment. In 2017 the worset water quality 
was in the Mixing and Central regions (Bad). The waters of the Dnipro-Bug region showed "High" enviromental quality ratio

As a result of monitoring for 2016, 2017 and 2019, the environmental class status in most of the investigated aquatories showed a "Bad" quality class, rarely "Moderate" or "Poor", "High" class of water quality was noted only in Danube region (in 2019 and 2016) and in Dnipro-Bug region (2017).

\section{SUMMARY}

The article presents the results of the reseach of the state of zooplankton, which were conducted during the Ukrainian-Georgian expedition in the summer and autumn 2019 in the framework of the international project "Emblas-plus". In 2019, a total of 23 samples were taken from 20 stations. A taxonomic analysis of the collected species was conducted, the abundance and biomass of zooplankton were calculated and the fish feed base of the Black Sea open water was analyzed. To determine the quality of the studied Black Sea waters according to the state of zooplankton used the following characteristics: total zooplankton biomass $\left(\mathrm{mg}^{*} \mathrm{~m}^{-3}\right)$, Noctiluca scintillans biomass (\% of total biomass), Copepod biomass (\% of total biomass), Jelly biomass: Scyphozoa, Hydrozoa and Ctenophora jellyfish (\% of total biomass) and the Shannon number index $\left(\right.$ Beat* $\left.^{*} \mathrm{ex}^{-1}\right)$. The ecological quality class of the investigated Black Sea waters was determined by the zooplankton integrated index (EQR). The quality class was assessed on a 5 point scale in accordance with the EU Water Framework Directive (WFD) standards: "High", "Good", "Moderate", "Poor" and "Bad" quality. Also was conducted a comparative analysis of the state of zooplankton and water quality for 2016, 2017 and 2019. It was found that at most of the stations the dominant role in the formation of zooplankton biomass was played by the organisms of forage zooplankton. In 2019, the average biomass of fish feed zooplankton was the highest in the three years of the investigation. Also, in three years, the best water quality was observed in summer 2019 (at all stations) and at most stations in 2017. The water quality was similar from 3 years. "High" class of water quality was noted only in Danube region (in 2019 and 2016) and in Dnipro-Bug region (2017).

\section{REFERENCES}

1. Александров Б.Г. Гидробиологические основы управления состоянием прибрежных экосистем Черного моря. Киев : Наукова думка, $2008.343 \mathrm{c}$.

2. Методические рекомендации по сбору и обработке материалов при гидробиологических исследованиях. Зоопланктон и его продукция. Ленинград : ЗИН, 1984. 35 с. 
3. Определитель фауны Черного и Азовского морей [Текст]: в 3 т. / под общ. ред. Ф.Д. Мордухай-Болтовского. Киев : Наукова думка, 1968. T. I: Свободноживущие беспозвоночные. Простейшие, губки, кишечнополостные, черви, щупальцевые. 437 с.

4. Определитель фауны Черного и Азовского морей [Текст]: в 3 т. / под общ. ред. Ф.Д. Мордухай-Болтовского. Киев : Наукова думка, 1969. T. II : Свободноживущие беспозвоночные. Ракообразные. 536 с.

5. Определитель фауны Черного и Азовского морей [Текст]: в 3 т. / под общ. ред. Ф.Д. Мордухай-Болтовского]. Киев : Наукова думка, 1972. T. III. Свободноживущие беспозвоночные. Членистоногие (кроме ракообразных), моллюски, иглокожие, щетинкочелюстные, хордовые. $340 \mathrm{c}$.

6. Руководство по организации и проведению биологического мониторинга на стационарных пунктах / Составители: Александров Б.Г. и др. Одесса, 2016. 6 с.

7. Сбор и обработка зоопланктона в рыбоводных водоёмах. Методическое руководство (с определителем основных пресноводных видов) / О.Е. Тевяшова. Ростов-на-Дону : ФГУП «АзНИРХ», 2009. 84 с.

8. Alexandrov B.G. General remarks on the method of quantitative accounting of zooplankton and the use of an integrated assessment of the state of zooplankton to determine the quality of the marine environment (calculation methodology, quality assessment scales). Workshop on the NPMS and JOSS Biological Monitoring Methods. 2016. URL: http://emblasproject.org/gallery/ npms-joss-biology-training.

9. Alexandrov B., Minicheva G., Zaitsev Yu. Black Sea network of marine protected areas: European approaches and adaptation to expansion and monitoring in Ukraine. Management of marine protected areas: a network perspective from the Mediterranean and Black Sea / Ed. by Paul D. Goriup. Wiley-Blackwell Publ., 2017. P. 259-282.

10. Aleksandrov B., Arashkevich E., Gubanova A., Korshenko A. Black Sea Monitoring Guidelines - Mesozooplankton. EU/UNDP Project: Improving Environmental Monitoring in the Black Sea - EMBLAS. Project Activity 3: Development of cost-effective and harmonized biological and chemical monitoring programmes in accordance with reporting obligations under multilateral environmental agreements, the WFD and the MSFD October 2014. $31 \mathrm{p}$.

11. Alexandrov B.G., Kharytonova Yu.V. Implementation of the EU Directive on the Marine Strategy for the Sovereign Monitoring of the Zooplankton of the Marine Waters of Ukraine. The European Interation of Environmental Policy of Ukraine : Materials of the All-Ukrainian Sciences. conf., Odessa, 29-31 May 2019, ODEKU. Odessa, 2019. P. 28-37. URL: http://odeku.edu.ua/wp-content/uploads/Zbirnik-materialiv- Ekopolitika.pdf 
12. Alexandrov B.G., Kharytonova Yu.V. Leadership on the zooplankton monitoring of Ukraine sea waters and the definition of their environmental standard EU Directive on Marine Srtategy. Odessa, 2019. 33 p.

13. DIRECTIVE 2008/56/EC of the European Parliament and of the Council establishing a framework for Community action in the field of marine environmental policy, 17 June 2008. (MSFD, 2008/56/EC).

14. Commission Decision (EU) 2017/848 of 17 May 2017 laying down criteria and methodological standards on good environmental status of marine waters and specifications and standardised methods for monitoring and assessment, and repealing Decision 2010/477/EU C/2017/2901. ELI: http://data.europa.eu/eli/dec/2017/848/oj \

15. Kharytonova Yu.V. Analysis of transition waters of the Ukrainian Black sea ahelf by zooplankton indicators (on example of the Danube Delta). Journal of the Odessa National University. Seriya: Biology. Volume 24, Issue 2 (45) 2019. Odessa ONU. P. 88-96.

16. Kharytonova Yu.V. Analysis of the ecological status of the northwestern part of the Black Sea of zooplankton indicators according to the standards of the EU Directive on Marine Strategy / Yu. V. Kharytonova, V.G. Dyadychko. Monitoring and Conservation of Biodiversity in Ukraine: Animal World. Series: Conservation Biology in Ukraine. Materials of the conference. Vip. 16. Vol. 2. Kyiv; Chernivtsi: Druk Art, 2020. P. 221-229.

\section{Information about authors: Kharytonova Yu. V., Engineer, PhD Student Institute of Marine Biology} of the National Academy of Sciences of Ukraine 6, Udilnyy lane, Odesa, 65012, Ukraine Nabokin M. V., Head of the Sector of Hidrobiological Studies Ukrainian Scientific Center of Ecology of the Sea

89, Frantsuzskyy blv., Odesa, 65009, Ukraine 